\title{
EDITORIAL
}

\section{A new Brazilian Journal of Pathology, Laboratory Medicine and Cytopathology}

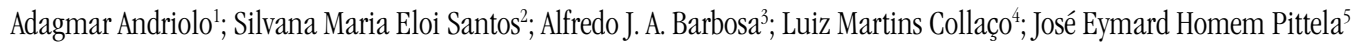

The year 2013 begins with excellent news for Brazilian Journal of Pathology and Laboratory Medicine (JBPML). The JBPML is the official publication of the Brazilian Societies of Pathology, Clinical Pathology/Laboratory Medicine and Cytopathology and is intended for the publication of scientific papers that contribute to the development of their corresponding areas of expertise.

The articles published in the Journal are indexed in Latin American Health Sciences (LILACS), in the Chemical Abstracts, and database Scientific Electronic Library Online (SciELO). In addition to the specialty societies, it receives financial support from National Council for Scientific and Technological Development (CNPq) and Coordination of Improvement of Higher Education Personnel (CAPES) and strategic support from the Ministries of Education and Science and Technology.

JBPML has a regular bimonthly print run of 3,600 copies, distributed to members of the respective specialty societies and libraries from academic institutions in Brazil and some Latin American countries. The following types of articles may be submitted: original articles, review articles (by invitation of the editors), update paper, case reports, short communications, letters to editors and book reviews.

Due to its relevance in the setting of national scientific journals, in 2012 JBPML participated in the process of performance evaluation conducted by the Advisory Board of SciELO, which included a review of formal aspects and content of the journal, the analysis of the use and impact indicators, punctuality in sending electronic files, as well as its suitability to the other evaluation criteria proposed by SciELO Brazil collection. The evaluation was highly positive and encouraging, prompting some recommendations, which were readily accepted by the scientific societies responsible for the publication of JBPML.

Thus, we chose the full publication of articles in the English language, a new graphical formatting of text and tables, as well as significant expansion of the scope of the members of the Editorial Board of Reviewers and ad hoc.

We believe that these changes will allow JBPML to remain the most prominent vehicle for the dissemination of knowledge in diagnostic areas of pathology, clinical laboratory and cytopathology and gain ground among international publications.

1. Professor associado do Departamento de Medicina da Escola Paulista de Medicina da Universidade Federal de São Paulo (UNIFESP); editor chefe do Jornal Brasileiro de Patologia e Medicina Laboratorial (JBPML).

2. Professora titular do Departamento de Propedêutica Complementar da Faculdade de Medicina da Universidade Federal de Minas Gerais (UFMG); editora da área de Medicina

Laboratorial.

3. Professor titular de Patologia da Faculdade de Medicina da UFMG; editor da área de Patologia.

4. Professor titular de Patologia da Faculdade de Medicina da UFMG; editor da área de Citopatologia.

5. Professor titular de Patologia da Faculdade de Medicina da UFMG; editor da área de Patologia. 